\title{
Which executive characteristics create value in banking? Evidence from appointment announcements
}

\author{
Duc Duy (Louis) Nguyen, Jens Hagendorff*, Arman Eshraghi \\ Corporate Governance: An International Review 23(2): 112-128
}

\begin{abstract}
Manuscript type: Empirical

Research Question/Issue: This study seeks to understand how the characteristics of executive directors affect the market performance of US banks. To explore the expected performance effects linked to executive characteristics, we measure any changes in the market valuation of banks linked to announcements of executive appointments.

Research Findings/Insights: Our study has two important findings. First, we show that age, education and the prior work experience of executives create shareholder wealth while gender is not linked to measureable value effects. Second, these wealth effects are moderated by the level of influence of incoming executives, with their magnitude diminished under independent boards and higher if the incoming executive is also appointed as CEO. Our results are robust to the treatment of selection bias.
\end{abstract}

Theoretical/Academic Implications: By illustrating the wealth effects linked to executive appointments, our study contributes to the current debate on whether and how individual executives matter for firm performance and behaviour. The findings also shed light on the value of human capital in the banking industry.

Practitioner/Policy Implications: This study offers important insights to policymakers charged with ensuring the competency of executives in banking. Our findings advocate policies that mandate banks to appoint highly qualified executives with relevant banking experience.

Keywords: Corporate Governance, Banks, Executives Characteristics, Market Value

The authors are with the University of Edinburgh, 29 Buccleuch Place, Edinburgh EH8 9JS, UK. *Corresponding author. Tel.: +44 1316502796. Email addresses: D.Nguyen@sms.ed.ac.uk (D.Nguyen), Jens.Hagendorff@ed.ac.uk (J.Hagendorff), Arman.Eshraghi@ed.ac.uk (A.Eshraghi). We are particularly grateful to Renée Adams for many helpful suggestions. We also thank Melsa Ararat, Jonathan Crook, Jo Danbolt, Hans van Ees, Heather FoustCoomings, Angelica Gonzalez, Ufuk Gucbilmez, Jakob de Haan, Anja Kirsch, Praveen Kumar (the Editor), Lucy Liu, Felix von Meyerinck, Corinne Post, Bill Rees, Siri Terjesen, Günseli Tümer-Alkan (the discussant), Denis Veltrop, Patrick Verwijmeren and participants at the 2013 De Nederlansche Bank conference on Diversity in Boards, 2014 FMA European meeting in Maastricht and seminar participants at the University of Edinburgh for useful comments. 


\section{INTRODUCTION}

There is a considerable debate amongst the public, policymakers and academics as to whether individual executives matter for firm performance and behaviour. A growing body of research demonstrates that executive directors are a heterogeneous group and suggests that executive behaviour is governed by more than economic trade-offs. Studies have shown that executives affect the performance of firms (e.g., Adams, Almeida, \& Ferreira, 2005; Bennedsen, PerezGonzalez, \& Wolfenzon, 2008; Custodio \& Metzger, 2013; Kaplan, Klebano, \& Sorensen, 2012) and their policy choices (e.g., Bertrand \& Schoar, 2003; Custodio \& Metzger, 2014; Malmendier, Tate, \& Yan, 2011). Other studies argue that individual executives have little impact on firm performance and behaviour because seemingly unique executive-specific 'styles' may in fact be shaped by the board of directors and that new executives are appointed with desired characteristics to take a firm in the direction determined by the board (Fee, Hadlock, \& Pierce, 2013). This study sheds new light on whether and how executives matter by demonstrating that variations in observable demographic and experience characteristics of executives have market valuation effects.

With existing work mostly limited to non-financial firms, there is an inherent lack of analysis concerning the banking sector. Since banks are complex institutions and may require employees with specialised skills (Philippon \& Reshef, 2012), selecting the right executives could give banks a significant competitive edge as well as contribute to the growth of the economy. Recently, the banking sector has received much criticism for its contribution to the financial crisis that started in 2007. Many blame incompetent banking executives for engaging in activities that endangered the safety and soundness of the financial system and gave rise to unprecedented government support of the banking sector. By the same token, certain bank 
executives have been credited with steering their organisations successfully through the financial crisis. $^{1}$

In this study, we focus on executive directors ${ }^{2}$ who are responsible for the day-to-day running of the bank. Since executive directors have substantial discretion over their decisions, their individual characteristics such as prior experience could make an important difference to bank outcomes (e.g. Kim \& Lu, 2014; Landier, Sauvagnat, Sraer, \& Thesmar, 2013). In contrast, non-executive directors, who are responsible for monitoring and advising the CEOs, are not involved in managing the bank on a daily basis. Hence, compared with non-executive directors, executives have more influence and their characteristics are more likely to have measurable implications for the market performance of banks.

We argue that executive characteristics such as age, education, and employment history are performance relevant. In our analysis, we examine whether the stock market reaction to the appointment of a new executive is driven by the characteristics of the appointee. Focusing on the appointment of a new executive offers an appropriate setting in which to examine the value of characteristics that the appointee brings to the hiring bank. In an efficient capital market, the market reaction is indicative of the anticipated future performance conditional on relevant information (Perez-Gonzalez, 2006; Warner, Watts, \& Wruck, 1988). Thus, market returns will be higher when an appointee with desirable characteristics is hired because investors believe that this appointee will improve performance. In this study, we do not look at internal appointments of executives because the identification of any causal effects between appointee characteristics and announcement returns are not straightforward in this case. From a resource-based perspective, the marginal addition in terms of human capital to the firm is likely to be smaller 
when internal candidates (who, most likely, already contribute to bank decision-making in senior positions) are appointed compared to an externally appointed director.

Our sample consists of 252 executive appointment announcements by 145 US banks. Exploring this dataset, we examine whether the stock market reaction to the appointment announcement is affected by seven characteristics of the appointee: (1) age, (2) gender, (3) the number of prior executive directorships, (4) the number of current non-executive directorships (busyness), (5) the number of non-banking industries (in which the appointee has experience), (6) an Ivy League education and (7) an MBA degree.

There are two main econometric challenges we face in our analysis. First, a bank's decision to make a top executive appointment could be driven by endogenous factors, e.g., when a bank is not performing well and faces shareholder pressure to improve performance by making new appointments (Berger, Kick, \& Schaeck, 2014; Fee et al., 2013). We therefore exclude appointments where the press coverage indicates an appointment followed investor dissatisfaction with management or corporate strategy. The second challenge is that, since we are interested in the expected performance effects linked to a new appointment, our sample only contains single appointment announcements which involve external appointments (i.e., executives who have previously not worked for the sample bank). This might introduce a selection bias when the decision to make a single (rather than multiple) appointment announcement or the decision to choose an external (rather than an internal) appointee correlates with factors associated with announcement returns. We address this second challenge using the Heckman (1979) two-step procedure and the findings we report in this paper are robust to controlling for selection bias. 
Our key findings are as follows. First, announcement returns following appointments are statistically positive, suggesting that the addition of top managers, on average, is valuable for US banks. Second, we examine whether the market reaction to executive appointments is influenced by characteristics of the executive. Overall, our findings suggest that the age, education and prior experience of the executives create shareholder wealth in the US banking sector. In contrast, gender, non-banking experience or an MBA degree do not lead to any measurable market returns. In addition, the appointment of executives who hold non-executive directorships with outside firm at the time of the appointment results in negative returns, consistent with the hypothesis that busy executives have less attention to focus on an individual bank (Fich \& Shivdasani, 2006).

Third, our analysis of interaction terms shows that the wealth effects linked to executive characteristics are moderated by how much influence the incoming executive is expected to hold over the bank. Thus, the expected performance effects of top executives are reduced as bank boards become more independent. By contrast, the expected performance effects are higher for CEOs, confirming that the CEO is the most important decision-maker in the bank.

Overall, our study makes three significant contributions to the literature. First, we contribute to a growing literature that uses manager fixed effects to address the question of how important executive 'styles' are to various corporate outcomes (Adams et al., 2005; Bamber, Jiang, \& Wang, 2010; Bertrand \& Schoar, 2003; Frank \& Goyal, 2007; Graham, Li, \& Qiu, 2012). It is empirically challenging to quantify the effects of individual executives on firm performance. Fee et al. (2013) argue that executive turnover, which forms the empirical basis to work out executive styles, may frequently be endogenous (e.g., when they follow a period of underperformance). When focusing on 'exogenous' CEO replacements brought about by CEO 
retirements and deaths, the authors do not find evidence of manager fixed effects in corporate policy choices. This raises the question whether or not the results of the manager styles literature are biased and that whether, more broadly, executives matter for corporate outcomes.

Our paper offers an alternative route to showing that executives indeed matter. Unlike Fee et al. (2013) we do not focus on executive 'styles', but on demographic and experience variables of executives. We show that the majority of executive appointments are linked to value gains around the announcement date. By analysing the variation in short-term returns following executive appointments, we can exclude events other than the appointment causing the observed effect. We thus interpret our results as evidence demonstrating that it matters who bank executives are in a similar way that much of the executive styles literature demonstrates.

Second, we provide direct empirical evidence on the value of top executive characteristics in the US banking sector. We are unaware of any published research that looks at the value of top executives in the banking sector. Since the banking sector is relatively opaque, complex and skill-intensive (Philippon \& Reshef, 2012), we contribute towards uncovering the 'black box' of desirable characteristics top corporate leaders should possess to affect performance in the banking sector. In addition, our findings add to the current debate on the value of generalist versus specialist managerial experience in banking. While many studies recognise the growing importance of general managerial experience (Custodio, Ferreira, \& Matos, 2013; Lazear, 2004), we show that cross-industry experience is not value-relevant to US bank shareholders.

Third, our paper contributes to the scant literature on governance inside the top management team. Despite the central roles CEOs and other executives play in managing the company, there are surprisingly few studies that focus on top executives (e.g., Berger et al., 
2014; Landier et al., 2013; Masulis \& Mobbs, 2011). Recently, Kim and Lu (2014) show how strengthening board independence weakens executive suite independence, which is proxied by the fraction of executives appointed before the current CEO. We similarly focus on the interplay between the boards and top management teams and demonstrate that board independence weakens the expected performance effects linked to certain executive characteristics.

This paper proceeds as follows. The next section surveys major theoretical and empirical evidence and develops our primary hypotheses, followed by a section describing our sample and empirical strategy. We then present our empirical results and conclude the paper.

\section{LITERATURE REVIEW}

\section{Theoretical background}

Much research in both non-financial and financial firms has devoted considerable attention to studying the board of directors. ${ }^{3}$ For example, recent studies analyse the effects of board size on firm value (e.g., Coles, Daniel, \& Naveen, 2008), the optimal balance between non-executive and executive directors (e.g., Dahya \& McDonnell, 2007; Dulewicz \& Herbert, 2004), the impact of board diversity on firm value (e.g., Carter, D’Souza, Simkins, \& Simpson, 2010; Erhardt, Werbel, \& Shrader, 2003), or the value of firm-level governance practices (e.g., Van Essen, Engelen, \& Carney, 2013; Ward, Brown, \& Rodriguez, 2009). There is also a stream of research that looks at the impact of gender diversity on firm performance (e.g., Adams \& Ferreira, 2009; Farrell \& ${ }^{1}$ Hersch, 2005; Rose, 2007; Singh, Vinnicombe \& Johnson, 2001). In the banking industry, Adams and Mehran (2012) and Andres and Vallelado (2008) show some evidence that bank board structure is relevant for bank performance. 
However, relatively little attention has been paid to top executives who are responsible for managing the bank on a daily basis. There remains considerable uncertainty around whether or not individual executives matter for corporate outcomes. Thus, neoclassical economics assumes that individuals are homogeneous and different executives are perfect substitutes for each other. Agency theory, while acknowledging that executives may pursue different courses of action to advance their personal interests, sees executive actions shaped by the quality of corporate governance in the organisation.

In contrast, the management literature and Hambrick and Mason's (1984) upper echelons theory suggests that individual characteristics matter. Upper echelons theory argues that executives' idiosyncratic experiences affect their interpretations of strategic decision-making situations and, in turn, affect their strategic choices and performance levels. Upper echelons theory predicts individual differences among executives will be most salient when the decisionmaking situations are complex and ambiguous as would be the case for banking organisations.

To summarise, existing theories make contradicting predictions regarding whether executives matter for firm outcomes. To shed light on this issue, we use variations in observable demographic and experience characteristics of executives to answer two key empirical questions: (1) whether executives matter and (2) how executives matter.

\section{Executive characteristics and bank performance}

In this section, we explain how demographic and experience characteristics of executives affect the announcement returns. The characteristics we focus on are (1) age, (2) gender, (3) the number of prior executive directorships, (4) the number of current non-executive directorships 
and (5) the number of non-banking industries (in which the executive has experience), (6) Ivy League education and (7) MBA degree.

Age. The age of the appointees could impact their decision-making capability, risk-taking behaviour, career concerns and economic incentives. Compared to younger appointees, older ones have more experience in making decisions when they face complex and ambiguous tasks (Worthy, Gorlick, Pacheco, Schnyer -et al. 2011). Furthermore, older appointees face less career uncertainty and have fewer incentives to improve their job security. Thus, they are less likely to engage in value-destroying excessively risky activities. For example, Yim (2013) shows that older CEOs are less likely to engage in M\&A activities and tend to perform better. Hence, older appointees could create wealth for bank shareholders.

However, younger appointees have more energy and drive (Harman, 1991; Roberts \& Rosenberg, 2006). This could translate into other characteristics such as enthusiasm, decisiveness and ambition. In addition, compared to older appointees, younger ones have more ideas, are quicker in learning new technologies (Grund \& Westergård-Nielsen, 2008) and are able to make innovative decisions. With these qualities, younger appointees may create shareholder wealth.

Gender. Female appointees possess unique skills, experience and networks, allowing them to contribute to the functional decision making capability of the bank. In addition, female appointees could counterbalance potentially excessive risk-taking behaviour by male colleagues. For example, Faccio, Marchica and Mura (2014) document that firms run by female CEOs have lower leverage, less volatile earnings, and a higher chance of survival than firms run by male CEOs. Since excessive risk-taking could destroy value, the appointment of a female executive could create wealth for bank shareholders. 
However, there is a possibility of conflict between the newly appointed female executive and the existing male executives. It may prove difficult for female executives to be listened to on an equal basis by other members if there are very few females on the board or in the executive suite (Terjesen, Sealy, \& Singh, 2009). This could impose psychic costs on the female executive, which could result in performance losses (Becker, 1957).

Empirical results that attempt to link the presence of female executives to firm performance are mixed. For example, Lee and James (2007) find a significant negative stock market reaction to the news of female CEO appointments while Gupta and Raman (2013) find no gender-specific difference in the stock reactions to the news of the CEO appointment or in the post-appointment operating performance of firms. Adams and Ferreira (2009) show that for firms with good corporate governance standards in place, more gender-diverse boards are negatively associated with firm performance.

Prior executive directorships experience. It is possible that there is a unique set of skills and managerial abilities acquired by those with prior executive directorships that sets them apart from other individuals (Fama, 1980; Fama \& Jensen, 1983). Hence, holding prior executive directorships in listed firms signals the appointee's proven track record and accomplishments. In addition, experienced appointees also bring their existing social ties and networks to the bank. This places the bank in the networks of other firms, giving it access to various external constituencies such as industry regulators (Hillman, Cannella, \& Paetzold, 2000). Looking at diversifying M\&A, Custodio and Metzger (2013) show that when the acquirer's CEO has prior experience working in the target industry, acquirer's abnormal announcement returns are higher than those generated by a CEO without similar experience. 
Current non-executive directorships (busyness). The appointment of an executive with non-executive directorships could give the bank 'endorsement benefits', allowing it access to corporate elites and external resources (Fich, 2005; Masulis \& Mobbs, 2011).

However, appointees holding non-executive directorships can be distracted from their responsibilities at the bank (Ferris, Jagannathan, \& Pritchard, 2003; Fich \& Shivdasani, 2006). They might not have the time and energy to fulfil their duties. Multiple directorships have been associated with lower board inputs from busy directors (Jiraporn, Davidson, DaDalt, \& Ning, 2009). Bar-Hava, Gu and Lev (2013) show that when busy directors resign from one of the board positions, investors of firms which the directors continue to serve react positively to the news. Finally, examining US commercial banks, Grove, Patelli, Victoravich and Xu (2011) show that the proportion of busy directors has a weak inverted-U relationship with bank performance.

Experience in non-banking industries. Several studies suggest that general skills acquired through experience in a diversified set of industries are becoming increasingly important and value-adding (e.g. Cremers \& Grinstein, 2013; Custodio et al., 2013; Lazear, 2004). This allows appointees to make a variety of decisions in different contexts. However, as the banking industry is highly specialised, appointees with experience in multiple non-banking industries might have fewer specialist financial skills and thus, might be less capable of making technical decisions.

Ivy League education. We choose Ivy League institutions ${ }^{4}$ as an indicator of highly reputable universities. While not a perfect proxy for academic excellence, there is empirical evidence showing that Ivy League graduates perform better than non-Ivy ones. For example, Laderman (1994) finds that during the period from the 1989-1993 period, mutual funds managed by Ivy League graduates generally outperform their non-Ivy counterparts. More recently, Falato, 
Li and Milbourn (2014) demonstrate that CEOs who study at more selective institutions are paid at a premium and this effect is associated with talent. In addition, Ivy League graduates often have access to certain elite groups including successful businesspeople or experts in their own areas.

However, Ivy League educated appointees might choose to engage only with peers with a similar educational background and refuse to collaborate with other members in the executive team. This could result in an unhealthy corporate culture where different social groups compete for power (Farnum, 1990). Since conflicts of social preference can impose psychic costs on team members and lower overall group performance (Becker, 1957), the presence of Ivy League educated appointees could destroy shareholder wealth.

MBA degree. One well-documented benefit of an MBA degree is the extensive social links that the appointees form during their MBA study. Appointing executives with an MBA degree could place the hiring bank in a more central position in the corporate social networks, and this could create value for bank shareholders.

However, there is no clear empirical evidence suggesting that MBA executives outperform non-MBA ones. For example, Chevalier and Ellison (1999) find that hedge fund managers with an MBA degree do not perform significantly better than those without one. Furthermore, McCabe, Butterfield and Trevino (2006) show that self-reported cheating is higher in MBA program than in other graduate programs. Since individuals who cheat at school also tend to cheat in the workplace (Nonis \& Swift 2001), MBA executives might be more likely to commit wrongdoing during their tenure at the bank. This could destroy shareholder wealth because the losses associated with corporate fraud can be enormous (Karporff, Lee, \& Martin, 2008). 
Overall, there are arguments for both positive and negative effects linked to the executive characteristics we discuss above. Therefore, it is ultimately an empirical question to see whether the director characteristics have positive or negative effects on shareholder wealth.

\section{DATA AND EMPIRICAL STRATEGY}

\section{Data}

We examine new appointments of executives to US banks from January 1999 to December 2011. We start by obtaining a list of all banks on BoardEx, a leading business intelligence service that provides information on executive characteristics. BoardEx covers in excess of 700 US banks which is far more than other similar databases which track executives over time, allowing us to also include smaller banks into our sample. Recently, several studies have used BoardEx to obtain director-level data. For example, Custodio et al. (2013) use it to track the lifetime work experience of S\&P 1500 CEOs and Van Essen et al. (2013) use it to obtain board characteristics of European firms. Since BoardEx covers executive-level information from 1999 onward in good detail, our sample period starts in 1999.

We then use Factiva to search for newspapers articles containing the search terms related to executives ('officer', 'executive' etc.) and appointments ('appoint', 'name' etc.). To avoid missing appointment events, we keep our search terms generic and avoid using specific terms such as 'executive director'. As in Custodio and Metzger (2013), we retain appointments to executive positions including CEO, CFO, COO, CRO, CIO, Chairman, President, Division CEO, Division President, Division Chairman, Head of Division, Regional CEO, Regional President, and Regional Chairman. Some of our executive appointments are simultaneously board appointments. This is the case for most CEO appointments and for a limited number of President or $\mathrm{COO}$ appointments. Since investors could react differently to appointments that mix the hiring 
of a new executive with board appointments, we will deal with this possibility in subsequent sections.

The event date is defined as the earliest trading day when the announcement is made. In the final sample, we impose two exclusion criteria to ensure that the stock market reaction is purely driven by the event of the incoming executive appointment. First, we remove all appointment announcements that are simultaneously announced with other corporate events (e.g. earnings or merger announcements) because the stock market reactions might be confounded by the other news items in these cases. Second, we exclude all appointment announcements that are made simultaneously with announcements of unplanned executive departures. We exclude these announcements, because the stock market reaction to this type of event might be driven by the predecessor's unplanned departure rather than by the incoming executive appointment. Planned departures (that is, previously announced executive departures due to retirement) are kept in the sample. ${ }^{5}$ We also remove appointment announcements where appointee information cannot be retrieved from BoardEx and where daily stock returns are not available from the Center for Research in Security Prices (CRSP) database. We then cross-check each announcement with information disclosed in BoardEx and in the bank's financial reports to verify the accuracy of the information.

This generates a set of 658 executive appointment announcements by 308 banks. Our 658 appointment announcements are classified into three categories: (1) single appointment announcements of externally-hired executives (252 cases), (2) single appointment announcements of internally-promoted executives (271 cases), and (3) appointment announcements where two or more executives are simultaneously appointed (135 cases). 
Our sample of interest consists of single and externally-hired appointment announcements. While differences in the announcement effects for externally- versus internallyhired directors are an interesting research question, this is beyond the scope of the present study. In this study, we restrict our sample to externally-hired executives to enable us to unambiguously measure the marginal value effect linked to the inclusion of new executives. Compared to an externally appointed director, the marginal addition in terms of human capital to the firm is likely to be smaller when internal candidates who already contribute to bank decision-making are appointed. Similarly, we cannot separate the announcement effects linked to individual executives when multiple executives are simultaneously appointed. However, focusing solely on external appointments could introduce a selection bias when banks choose to make external appointments over types of appointments. We will deal with this potential selection bias in subsequent sections. Table 1 summarises our classification of 658 executive appointment announcements.

Insert Table 1 about here

We obtain data on appointee characteristics from BoardEx. We first include two basic demographic measures: AGE measures the age of the appointee at the time of the appointment and FEMALE is a dummy that that equals to 1 if the appointee is a female and 0 otherwise. Second, we include three variables that capture the appointee experience and competitiveness in the external labour market: \#EXECUTIVE DIRECTORSHIPS measures the number of executive directorships with listed firms that the appointee has held prior to joining the bank. BUSYNESS measures the number of non-executive directorships the appointee holds at the time of the appointment. \#NON-BANKING INDUSTRIES measures the number of non-banking 
industries (based on 4-digit SIC codes) the appointee has worked in prior to joining the bank. Finally, we include two variables that capture executive educational background: IVY LEAGUE is a dummy that equals 1 if the appointee obtains at least one degree from Ivy League institutions and 0 otherwise and MBA is a dummy that equals 1 if the appointee possesses an MBA degree and 0 otherwise.

\section{Empirical strategy}

Our main purpose is to investigate how market investors evaluate appointee characteristics using the stock market reactions to executive appointments. Since our approach is to employ only single appointment announcements involving appointees external to the bank, we face two main challenges.

First, the bank decision to make an executive appointment could be driven by endogenous factors, e.g., when it is not performing well and faces shareholder pressures to improve its performance by making new appointments (Berger et al., 2014; Fee et al., 2013). The stock market reaction to such appointments, therefore, could be driven by investor satisfaction with the bank decision to take action rather than the performance effects linked to a new appointment. Since we are interested in examining how appointee characteristics are evaluated by market investors, we exclude appointment announcements that are made because the bank is not performing well. We rely on the contents provided in the press coverage to judge whether an appointment is made due to poor performance. In particular, if there is information indicating that the appointment is made because the bank is facing 'disappointing performance' or trying to 'seek a turnaround' for example, we do not include such appointment announcements in our sample. 
The second challenge is that using only the sample of single and externally-hired executive appointment announcements might introduce a selection bias. This happens when the decision to make a single external appointment correlates with factors which also explain the announcement returns. For example, if underperforming banks are more likely to make single external appointment announcements and this causes negative returns, then ignoring this possibility will bias our estimates.

By observing single external appointments jointly with other appointment types (i.e., multiple executive appointments and single, internal executive appointments), we are able to address this problem using the Heckman (1979) two-step procedure. In the first step, we construct a probit model to estimate the probability that the bank will make a single and externally-hired executive appointment announcement. We let a dummy variable be equal to 1 if the bank makes a single external announcement and 0 otherwise. The value of $q$ would be determined by:

$$
\mathrm{q}=\varsigma^{*} \mathbf{Z}+\varepsilon
$$

where $\mathbf{Z}$ contains appointee-level and bank-level variables that may influence the bank's decision to make a single and externally-hired appointment. The predicted individual probabilities obtained in the probit model are then used to calculate the inverse Mill's ratio for inclusion in the second-stage model as an additional explanatory variable (Heckman, 1979). Essentially, this procedure allows us to take into account the potential selection bias when banks choose to make a single external appointment instead of other appointment types. In the secondstep, we estimate the following regression model to examine the effects of appointee characteristics on the announcement returns:

$$
\text { 5-day } \operatorname{CAR}(\%)=\alpha+\beta_{1} \text { appointee characteristics }+\beta_{2} \text { control variables }+\beta_{3} \sigma \frac{\phi(q)}{\Phi(q)}+\varepsilon
$$


The second-step regression can now be updated by including the term $\phi(q) / \Phi(q)$ in the regression, where $\phi(q) / \Phi(q)$ is the inverse Mill's ratio (Heckman, 1979). The dependent variables are 5-day CAR (\%) around the announcement of a single externally-hired executive appointment. Appointee characteristics measures are defined as previously. Control variables refer to a set of variables that we include to ensure that our results on appointee characteristics are robust to the inclusion of these variables in the regression. We cluster standard errors at the bank-level.

The Heckman procedure requires us to identify an instrument in the form of a variable that influences the first step (the probability that a bank makes a single external appointment), but not the second-step (the appointment announcement CARs). We use the natural logarithm of the distance from the bank's headquarter to an international airport as an instrument (see Adams, Akyol and Verwijmeren (2013) for a detailed discussion of this instrument). The economic rationale behind this instrument is that banks with better access to a good talent pool are more likely to hire externally. Furthermore, holding all else constant, better-located banks are more attractive to talented executives and this could motivate them to move to work for the bank. Thus, these banks are less constrained in choosing executives and are more likely to hire externally. In addition, other than affecting the bank's access to local director pool, there is no reason to believe that this instrument would affect the announcement returns to director appointment. Thus, we postulate that this is a suitable instrument for our model.

\section{DETERMINANTS OF SINGLE \& EXTERNALLY-HIRED EXECUTIVE APPOINTMENTS}

We first study the characteristics of appointees and banks that make single and externally-hired executive appointments. Our model reports the probit estimates where the dependent variable 
equals 1 if banks make a single external executive appointment and 0 otherwise. This analysis is estimated over the population of appointment announcements (which includes our sample of single appointment announcements of externally-hired executives as well as single appointment announcements of internally-promoted executives and appointment announcements where multiple executives are appointed to executive and board positions).

The explanatory variables we include are appointee-level and bank-level variables. Appointee-level variables are the seven appointee characteristics defined as previously. We then include bank-specific variables, including bank size, which is the natural logarithm of the bank total assets (BANKSIZE); charter value, which is the ratio between the market value of equity and book value of equity (CHARTERVALUE); bank liabilities, which is the ratio of total (book) liabilities to the book value of equity (LEVERAGE). We further control for bank portfolio risk using the ratio of risk-weighted assets to the book value of total assets (PORTFOLIO RISK). We also control for the prior bank performance using an accounting-based performance measure: return on assets (ROA), which is the ratio of net income to total assets. All bank-specific variables are lagged at time $(t-1)$. Bank accounting information is collected from fourth quarter Consolidated Financial Statements for Bank Holding Companies (BHCs), i.e. Form FR 9Y-C from the Federal Reserve Board database.

We also include a set of bank governance variables that could have significant impacts on the probability of banks making a single external appointment. We include board characteristics, such as the total number of executive and non-executive directors on the board (BOARDSIZE), the proportion of non-executive directors on the board (BOARDIND), and whether the CEO is also a chairman (DUALITY). Furthermore, since the nominating committee is responsible for searching for and nominating executives, we add a dummy variable that equals 1 if the CEO sits 
on the nominating committee and 0 otherwise (CEOINNOMI). When the bank does not have a standing nominating committee, CEOINNOMI takes the value of 1. Data on bank governance are collected from BoardEx. Finally, we add a dummy variable to indicate whether the incoming executive joins as a CEO (CEOPOST) and whether the appointment is made after the 2008 financial crisis (POST_CRISIS). Table 2 shows the summary statistics and variable definitions.

Insert Table 2 about here

Table 3 shows the pairwise correlations between the variables.

Insert Table 3 about here

Table 4 presents the results of the first-stage probit regression. Consistent with our expectations, column 3 of table 4 shows that the natural logarithm of distance to a major airport is negatively related to the likelihood of single external appointments (Column 3: $\beta=-0.22$, $\mathrm{p}<.001)$ confirming its statistical validity as an instrument. In terms of appointee-level variables, the probability of a single external appointment is higher when the appointees possess an Ivy League education (Column 1: $\beta=0.30, \mathrm{p}<.10$ ). This could be because, in deciding between different potential candidates, banks tend to look for an unambiguous signal of competence. An Ivy League education could easily allow one candidate to stand out from other candidates. In addition, a single external appointment is more likely to include appointees with an MBA degree (Column 1: $\beta=0.50, \mathrm{p}<.001$ ) and is less likely to include those having prior executive directorship experience (Column 1: $\beta=-0.38, \mathrm{p}<.001)$.

Insert Table 4 about here 
In terms of bank-level characteristics, our results indicate that the growth prospect of the bank, measured by CHARTER VALUE, is inversely related to the likelihood of single external appointment (Column 1: $\beta=-0.18, \mathrm{p}<.01$ ). This finding supports the notion that banks look for external human capital when they need someone with new perspectives to enhance their growth potential. Finally, banks are less likely to appoint an external candidate to a CEO position (Column 1: $\beta=-0.56, \mathrm{p}<.001)$. This result is consistent with Cremers and Grinstein (2013), who report that external CEO succession is much less common than internal CEO succession in the banking industry.

In essence, along with appointee-level characteristics, bank-level characteristics differ systematically for firms that make the single external appointments contained in our sample as opposed to other types of appointments. Therefore, not accounting for these differences could bias our estimates of the expected performance effects linked to director appointments.

\section{EVENT STUDY METHODOLOGY AND RESULTS}

\section{Event study methodology}

We use event study methodology to examine the stock market reactions to single and externallyhired appointment announcements $(\mathrm{N}=252)$. Following prior studies on executive appointments, we concentrate on the time period immediately surrounding the appointment announcement. Specifically, we estimate the following market model:

$$
R_{i t}=\alpha_{i}+\beta_{i} R_{m t}+\varepsilon_{i t} t=-300, \ldots,-46
$$

where $\mathrm{R}_{\mathrm{it}}$ are the daily stock returns for firm $i$ at day $t$ and $R_{m t}$ are equally-weighted CRSP index return for day $t$. We estimate the model parameters using 255 daily return observations starting 
from 300 to 46 days before the executive announcement date. We specify that there is no other executive appointment made during this estimation period. For robustness, we also use a different estimation period $(-146,-46)$ and a different market benchmark (Datastream All US Banks Index). We construct abnormal returns as the sum of the prediction errors of the market model. To test for the statistical significance of the abnormal returns (ARs) and the cumulative abnormal returns (CARs), we run the Patell-Z test and the Wilcoxon sign-ranked test.

\section{Event study results}

Table 5 presents the cumulative abnormal returns (CARs) surrounding single and externally-hired executive appointment announcements. CARs are calculated for two-, three-, four- and five-day event windows from day -1 to 0,0 to $+2,0$ to +3 and 0 to +4 ( 0 is the appointment date). The choice of event windows is motivated from the observation that the appointee is new to investors. Hence, investors require time to do their research on the appointee before they could accurately evaluate the appointee's impact on bank performance. Thus, this is likely to take a couple of days until a reliable and market price-moving assessment can be made. Table 5 shows that the stock market reaction to the appointment news, on average, is positive. Two-day $(-1,0)$, three-day $(0,+2)$, four-day $(0,+3)$ and five-day $(0,+4)$ CARs are $+0.71 \%$, $+0.31 \%,+0.47 \%$ and $+0.99 \%$, respectively. We observe that shorter event windows such as twoday $(-1,0)$ or three-day $(0,+2)$ are not statistically significant while longer event window of $(0$, +4 ) is significant (at $5 \%$ level for mean and median significance tests). Hence, this validates our expectation that there is a lag in the stock market reaction to the appointment news.

Insert Table 5 about here 
Although the average CAR is positive, CARs are not always positive. For example, 118 out of 252 executive appointments (46.8\%) are associated with negative returns over 5-day window. Therefore, the next sections of this paper will investigate the determinants of stock market reactions to single and externally-hired executive announcements.

\section{REGRESSION RESULTS}

\section{Appointee characteristics and appointment announcement returns}

In this section, we investigate the relationship between the announcement effects and various appointee characteristics. The dependent variables are CAR of 5-day window $(0,+4)$ around the announcement of an executive appointment. Appointee characteristics measures are defined as previously. We include a set of control variables identical to those in Table 4 to ensure that our results on appointee characteristics are robust to the inclusion of these variables in the regression.

Table 6 shows the results of our second-stage regressions against 5-day CAR (\%). In columns 1, 3, 6 and 8, we show that the stock market returns are positively and significantly related to three appointee characteristics: (1) age, (2) number of executive directorships, and (3) Ivy League education. The magnitude for each of the coefficient estimates is generally consistent across columns. The coefficient estimates indicate that CARs are on average $1.2 \%$ higher when the appointee is 10 years older, $1.4 \%$ higher when the appointee has one prior executive directorships position and 3.5\% higher when the appointee has an Ivy League education.

Insert Table 6 about here

With respect to age (Column 1: $\beta=0.12, p<.10)$, among several possible explanations, we argue that younger appointees have more incentives to increase their job security by engaging in risky 
and value-destroying activities. Thus, market investors react less favourably to the appointment of a young appointee because they envisage that this appointment will impose an additional agency cost to the bank.

The positive coefficient estimates for number of executive directorships (Column 3: $\beta=1.36, \mathrm{p}<.05)$ demonstrate that prior experience performing functional tasks as a top executive equips the appointee with the most relevant expertise and skills to excel in the new job (Gary \& Nowland, 2013). We obtain similar estimation results when narrowing the definition of 'executive directorships' to 'CEO directorships'.

Columns 2, 5, 7 and 8 show that stock market returns are not affected by three executive characteristics: (1) being female, (2) number of non-banking industries, and (3) having an MBA degree. ${ }^{6}$ Thus, our findings suggest that the gender of the executive does not matter, in the eyes of investors, for their future performance in the bank. However, our insignificant results should be interpreted with caution. It is plausible that there is information leakage surrounding the appointment of executives, particularly around the appointment of high-profile female appointments. Prior to the announcement, there could be speculation about the potential candidates and their chances of being appointed. If this is the case, the appointment news would not come as a surprise to market investors, which could explain the lack of a reaction on the announcement date. Thus, information leakage could undermine the statistical significance of some of our estimation coefficients.

Columns 4 and 8 show that the coefficient estimates for busyness are statistically significant and negative (Column 4: $\beta=-3.27, \mathrm{p}<.01$ ). The magnitude of the coefficient is economically large, indicating that CARs are 3.27\% lower for each additional non-executive 
directorship the appointee holds. Hence, investors expect banks appointing busy executives to perform significantly worse than those appointing more committed executives.

The coefficients on the control variables generally have the expected signs. BOARDIND is positive and significant (Column 2: $\beta=10.60, \mathrm{p}<.05$ ), implying that the board makes better executive appointment decisions when it is highly independent. Announcement returns are also higher when the banks perform well as indicated by ROA (Column 2: $\beta=1.27, \mathrm{p}<.10$ ). By contrast, CHARTER VALUE is statistically negative (Column 2: $\beta=-2.07, \mathrm{p}<.01$ ), demonstrating that investors react more positively to single and externally-hired appointments when the bank growth rate is low. Thus, investors expect the externally-hired executive to bring new perspectives and ideas and improve the bank growth opportunities.

Another interesting finding is that LAMBDA is statistically positive in several specifications (e.g. Column 2: $\beta=7.53, \mathrm{p}<.001$ ). Lambda controls for selection bias caused by a bank's decision to make a single external appointment (rather than a different type of appointment). The positive coefficient on LAMBDA implies that the factors motivating banks to make a single external executive appointment correlate with positive announcement returns and that results not controlling for this will be biased.

\section{Alternative specifications and robustness checks}

We repeat the regression analysis in column 8 of Table 6 using different event-study specifications. Column 1 of Table 7 reports the coefficient estimates using a 4-day event window $(0,+3)$. Column 2 uses a shorter estimation period of $(-146,-46)$ and column 3 uses Datastream All US Banks Index (BANKSUS) as an alternative benchmark to calculate abnormal returns. Columns 1-3 show that our estimation results are similar to those of the previous section. 
Overall, our findings are insensitive to choices of event windows, estimation periods and benchmark types.

Insert Table 7 about here

Furthermore, although the text contained in the appointment announcements made by banks are standardised, the text in a few announcements might go beyond simply announcing the new executive. For example, one announcement in our sample explains that a new chief risk officer is appointed because the bank is currently battling with regulatory authorities and needs to improve its image after a scandal. Therefore, the stock market reactions could be interspersed with information other than those related to the new appointee. We exclude 10 such announcements and redo the analysis we did in column 8 of Table $6 .^{7}$ As column 4 of Table 7 shows, our new coefficient estimates are similar to those obtained previously. In addition, as some of the banks appear several times in our working sample, we add bank fixed-effects into our model. Column 5 shows that our results remain qualitatively similar to those obtained earlier.

To show that the estimation results we obtain in Table 6 are non-random, we run a placebo test during a 3 -day event window $(-15,-13)$. Since this event window is before the appointment announcement date, we expect none of the main coefficient estimates to take significant values. Column 6 of Table 7 confirms this expectation. This shows that the results we obtain in our main analysis in Table 6 are indeed driven by the event of the incoming executive appointment.

\section{Does board independence moderate the market valuation of executive characteristics?}


In Table 8, we examine whether the proportion of non-executive directors (BOARDIND) influences the market evaluation of appointee characteristics. More non-executive directors on the board implies more monitoring pressure on the top executives. Thus, a board with more nonexecutive directors could inhibit executive influence and, thus, diminish the expected performance effects linked to the appointee characteristics. To verify this, we include several interaction terms which are the products of executive characteristics and the proportion of nonexecutive directors, such as BOARDIND*AGE into our regression model.

Panel A of Table 8 shows that board independence has a statistically negative effect on investor evaluation of (1) Ivy League education $(\beta=-6.54, \mathrm{p}<.05)$, (2) \# executive directorships $(\beta=-7.12, p<.05)$ and (3) number of non-banking industries (in which the executive has experience) $(\beta=-21.78, \mathrm{p}<.10)$. Although insignificant, board independence also exerts a negative effect on investor evaluation of executive's age.

Insert Table 8 about here

To further investigate whether board independence diminishes the wealth effects of executive characteristics, we construct an F-test, the results of which are displayed in Panel B of Table 8. Our results demonstrate that the more a board is dominated by non-executive directors, market returns become less affected by characteristics of the executive. This is consistent with the prediction that non-executive directors act as monitors to inhibit top executive discretion and influence. Thus, when the level of influence of the incoming executive is diminished, their characteristics become less relevant to investors. Consequently, in a highly independent board, the positive wealth effects of executive characteristics disappear. 
Overall, we argue that executives are valuable for shareholders except when the board of directors is highly independent. In such cases, executives become value irrelevant.

\section{Are CEOs different?}

In Table 9, we examine whether the CEO dummy (CEOPOST) influences the market evaluation of appointee characteristics. In our sample of executive appointment announcements, we mix CEOs with other executives such as CFOs or CROs. Because the CEO is the most important decision maker in the bank, investors might value CEO characteristics differently from those of lower-ranked executives. Thus, we include several interaction terms which are the products of appointee characteristics and CEO dummy, such as CEOPOST*AGE into our regression model.

Panel A of Table 9 shows that CEOPOST has a positive effect on investor evaluation of: (1) Ivy League education $(\beta=3.77, p<.05)$ and (2) number of executive directorships ( $\beta=1.59$, $\mathrm{p}<.05)$. This implies that market investors place additional reward on talented and experienced CEOs relative to other executives. By contrast, CEOPOST has a negative effect on investor evaluation of (3) busyness $(\beta=-10.45, \mathrm{p}<.001)$. Consequently, investors place an additional value cost on a CEO who is busy holding too many non-executive directorships. Thus, we observe a negative interaction term.

Insert Table 9 about here

To further investigate the wealth effects of CEO characteristics, we construct another Ftest in Panel B of Table 9. Panel B shows that the wealth effects of all characteristics are enhanced when the appointee joins as a CEO. In essence, our results show that, in the case of 
CEOs, investors value desirable characteristics more and penalise undesirable characteristics more.

Finally, some appointment announcements entail the appointee also being appointed to the board of directors. This happens in most CEO appointments and in some President appointments. Since we have already found stronger wealth effects linked to CEO appointment, we examine whether hiring mixed with board appointment to non-CEO positions also causes larger valuation effects. Overall, the interaction coefficients are insignificant, implying that investors do not place additional value on this appointment type. For brevity, we do not report the results.

\section{DISCUSSION AND CONCLUSION}

Our paper investigates the value of executives to shareholders of US banks by examining the stock market reaction to the appointment of new executives. Our argument is that if executives are valuable to shareholders, announcement returns will be higher when executives with certain desirable characteristics are appointed to a bank. We employ an event study to compute the expected performance gains linked to executive characteristics such as age, education and experience.

Using a hand-collected of 252 executive appointments from 1999 to 2011, we demonstrate that certain executive characteristics create shareholder wealth. In particular, we show that market returns are higher when the appointee is older, has prior experience as an executive director or holds an Ivy League degree. By contrast, the appointment of an executive who holds multiple non-executive directorships results in negative returns. In addition, the 
gender of the appointee and experience in non-banking industries do not affect stock market returns around the announcement of a new executive.

More importantly, we show that the level of influence that the appointee is expected to exert on the bank moderates the value which shareholders attach to appointee characteristics. We first document that the wealth effects disappear or diminish substantially the higher the proportion of non-executive directors. This implies that increased board monitoring and involvement in board decision making of non-executive directors reduces the influence of the incoming executive and therefore diminishes any wealth effects linked to their appointment. In addition, our findings demonstrate that the wealth effects are enhanced when the appointee joins as a CEO, consistent with the view that the CEO is the most important decision maker in the bank.

Overall, our study complements existing literature on why and how individual executives matter for firm performance. Our re ${ }^{8}$ sults stress the crucial role of the nominating committee, which is responsible for searching and hiring directors (Shivdasani \& Yermack, 1999). Our results also have important policy implications. First, we echo de Haan and Vlahu (2013) that appointing more executives with expertise to the bank is an important policy concern. Our findings are consistent with calls by policy makers to appoint more executives that are highly qualified and possess relevant industry experience. Second, our study does not show that the expected performance effects linked to executives vary by gender. Since it is plausible that there is information leakage surrounding the appointment of high-profile female executives, it is difficult to rely on the event study results to conclude whether increasing the proportion of female executives will affect bank performance. Therefore, our results also highlight the difficulty in using event study evidence in the debate concerning gender diversity. 


\section{Endnotes}

${ }^{1}$ For example, John Stumpf from Wells Fargo and Jamie Dimon from JPMorgan are often cited as successful bank executives. See 'Jamie Dimon, the last King of Wall Street', Financial Times, 17 May 2013.

${ }^{2}$ We follow Custodio and Metzger (2013) in defining top executives. They include CEO, CFO, COO, CRO, CIO, Chairman, President, Division CEO, Division President, Division Chairman, Head of Division, Regional CEO, Regional President, and Regional Chairman.

${ }^{3}$ See Adams, Hermalin and Weisbach (2010) and de Haan and Vlahu (2013) for a review on recent developments of corporate governance literature in the non-financial and financial industries respectively. See also Song and Thakor (2006) for an analysis of the advisory role of the boards.

${ }^{4}$ Ivy League institutions are eight North Eastern American higher education institutions, including Brown University, Columbia University, Cornell University, Dartmouth College, Harvard University, Princeton University, University of Pennsylvania and Yale University.

${ }^{5}$ Since investors are already aware of the retirement of the outgoing executive, we argue that the stock market reactions to planned retirement announcements are purely driven by the joining event of the incoming executive

${ }^{6}$ Table 3 indicates a high correlation of 0.56 between the number of non-banking industries and number of current non-executive directorships (busyness). Thus, in column 8 , we exclude the number of prior non-banking industries to prevent the problem of multicollinearity.

${ }^{7}$ Among the excluded announcements, two contain political sentiments and eight point out the specific rationale behind the appointment. The rationales include: stabilising bank operations (two cases), improving bank image after the scandal (one case), making aggressive expansion into a new product market or geographical area (five cases). 


\section{REFERENCES}

Adams, R.B., Akyol, A.C., \& Verwijmeren, P. 2013. Director skill sets. Working paper

Adams, R.B., Almeida, H., \& Ferreira, D. 2005. Powerful CEOs and their impact on corporate performance. Review of Financial Studies, 18(4): 1403-1432

Adams, R.B., \& Ferreira, D. 2009. Women in the boardroom and their impact on governance and performance. Journal of Financial Economics, 94: 291-309

Adams, R.B., \& Mehran, H. 2012. Bank board structure and performance: Evidence from large bank holding companies. Journal of Financial Intermediation, 21(2): 227-248

Adams, R.B., Hermalin, B.E., \& Weisbach, M.S. 2010. The role of boards of directors in corporate governance literature: A conceptual framework and survey. Journal of Economic Literature, 48(1): 58-107

Andres, P.E., \& Vallelado, E. 2008. Corporate governance in banking: The role of the board of directors. Journal of Banking and Finance 32 (12): 2570-2580

Bamber, L.S., Jiang, X., \& Wang, I.Y. 2010. What's my style? The influence of top managers on voluntary corporate financial disclosure, The Accounting Review, 85(4): 1131-1162

Bar-Hava, K., Gu, F., \& Lev, B. 2013. Busy directors are detrimental to corporate governance health, Working paper

Becker, G.S. 1957. The economics of discrimination. Chicago: University of Chicago Press.

Berger, A., Kick, T., \& Schaeck, K. 2014. Executive board composition and risk taking. Journal of Corporate Finance. Forthcoming

Bennedsen, M., Perez-Gonzalez, F., \& Wolfenzon, D. 2008. Do CEOs matter? Working paper

Bertrand, M., \& Schoar, A. 2003. Managing with style: The effects of managers on firm policies. The Quarterly Journal of Economics, 118(4): 1169-1208

Carter, D.A., D’Souza, F., Simkins, B.J., \& Simpson, W.G. 2010. The diversity of corporate board committees and financial performance. Corporate Governance: An International Review, 15 (5): 396-414

Chevalier, J., \& Ellison, G. 1999. Are some mutual funds better than others? Cross-sectional patterns in Behavior and Performance. Journal of Finance, 54 (3): 875-899

Coles, J., Daniel, N., \& Naveen, L. 2008. Boards: Does one size fit all? Journal of Financial Economics, 87: 329-356.

Cremers, M., \& Grinstein, Y. 2013. Does the market for CEO talent explain the controversial CEO pay practices? Review of Finance. Forthcoming

Custodio, C. \& Metzger, D. 2013. How do CEOs matter? The effect of industry expertise on acquisition returns. Review of Financial Studies, 26(8): 2007-2047

Custodio, C. \& Metzger, D. 2014. Financial expert CEOs: CEO's work experience and firm's financial policies. Journal of Financial Economics, Forthcoming.

Custodio, C., Ferreira, M.A., \& Matos, P. 2013. Generalists vs. Specialists: Life time work experience and chief executive officer pay. Journal of Financial Economics, 108: 471492

Dahya, J., \& McConnell, J.J. 2010. Board composition, corporate performance, and the Cadbury committee recommendation. Journal of Financial and Quantitative Analysis, 42 (3): 535-564

de Haan, J., \& Vlahu, R. 2013. Corporate governance of banks: A survey. DNB Working paper No.386/July 2013. 
Dulewicz, V., \& Herbert, P. 2004. Does the composition and practice of boards of directors bear any relationship to the performance of their companies? Corporate Governance: An International Review, 12(3): 263-280.

Erhardt, N.L., Werbel, J.D., \& Shrader, C.B. 2003. Board of director diversity and firm financial performance. Corporate Governance: An International Review, 11(2): 102111.

Faccio, M, \& Marchica, M., \& Mura, R. 2014. CEO gender, corporate risk-taking, and the efficiency of capital allocation. Working paper.

Falato, A., Li, D., \& Milbourn, T.T. 2014. Which skills matter in the market for CEOs? Evidence from pay for CEO credentials. Management Science. Forthcoming

Fama, E.F. 1980. Agency problems and the theory of the firm. The Journal of Political Economy, 88 (2): 288-307.

Fama, E.F., \& Jensen, M.C. 1983. Separation of ownership and control. Journal of Law \& Economics, 26 (2): 301-25.

Farnum, R. 1990. Prestige in Ivy League: Meritocracy at Columbia, Harvard and Penn: 18701940. Dissertation available from ProQuest

Farrell, K.A., \& Hersch, P.L. 2005. Additions to corporate boards: The effect of gender. Journal of Corporate Finance, 11(1-2): 85-106.

Fee, C.E., Hadlock, C.J., \& Pierce, J.R. 2013. Managers with and without style: Evidence using exogenous variation, Review of Financial Studies, 26 (3): 567-601

Ferris, S.P., Jagannathan, M., \& Pritchard, A.C. 2003. Too busy to mind the business? Monitoring by directors with multiple boards appointments. Journal of Finance,58(3): 1087-1112

Fich, E. 2005. Are some outside directors better than others? Evidence from directors appointments by Fortune 1000 firms, Journal of Business, 78 (5): 1943-1971

Fich, E., \& Shivdasani, A. 2006. Are busy boards effective monitors? Journal of Finance, 61 (2): 689-724.

Frank, M., \& Goyal, V.K. 2007.Corporate leverage: How much do managers really matter? University of Minnesota and Hong Kong University of Science and Technology working paper

Gary, S., \& Nowland, J. 2013. Is prior director experience valuable? Accounting and Finance, 53 (3): 643-666

Graham, J. R., Li, S., \& Qiu, J. 2012. Managerial attributes and executive compensation. Review of Financial Studies, 25:144-86.

Grove, H., Patelli, L., Victoravich, L.M., \& Xu, P. 2011. Corporate governance and performance in the wake of the financial crisis: Evidence from US commercial banks. Corporate Governance: An International Review, 19(5): 418-436

Grund, C., \& Westergaard-Nielsen, N. 2008. Age structure of the workforce and firm performance. International Journal of Manpower, 29(5): 410-422

Gupta, A., \& Raman, K. Female CEOs. Working paper

Hambrick, D.C., \& Mason, P.A. 1984. Upper echelons: The organization as a reflection of its top managers. Academy of Management Review, 9 (2): 193-206.

Harman, D. 1991. The aging process: Major risk factor for disease and death. Proceedings of the National Academy of Sciences, 88: 5360-5363

Heckman, J.J. 1979. Dummy endogenous variables in a simultaneous equation system. Econometrica, 46: 931-959 
Hillman, A.J., Cannella, A.A., \& Paetzold, R.L. 2000. The resource dependence role of corporate directors: Strategic adaption of board composition in response to environmental change. Journal of Management Studies, 37(2): 235-256

Jiraporn, P., Davidson, W. N., DaDalt, P., \& Ning, Y. 2009. Too busy to show up? An analysis of directors' absences. Quarterly Review of Economics and Finance, 49: 1159-1171

Kaplan, S., Klebanov, M., \& Sorensen, M. 2012. Which CEO characteristics and abilities matter? Journal of Finance, 67: 973-1003.

Karporff, J.M., Lee, D.S., \& Martin, G.S. 2008. The cost to firms of cooking the books. Journal of Financial and Qualitative Analysis, 43: 581-612

Kim, E.H. \& Lu, Y. 2014. Dynamics between the executive suite and board independence. Working paper

Laderman, J.M. 1994. Business Week's guide to mutual funds. McGraw-Hill

Landier, A., Sauvagnet J., Sraer, D., \& Thesmar, D. 2013. Bottom-up Governance. Review of Finance, 17(1): 161-201

Lazear, E. 2004. Balanced skills and entrepreurship. American Economic Review, 94:208-11

Lee, P.M., \& James, E.H. 2007. She'-e-os: Gender effects and investor reactions to the announcements of top executive appointments. Strategic Management Journal, 28(3): $227-241$

Malmendier, U., Tate, G., \& Yan, J. 2011. Overconfidence and early-life experiences: The effects of managerial traits on corporate financial policies. Journal of Finance, 66: $1687-1733$

Masulis, R.W., \& Mobbs, S. 2011. Are all inside directors the same? Evidence from external directorships market. Journal of Finance, 66:823-872

McCabe, D. L., Kenneth, D.B., \& Linda, K.T. 2006. Academic dishonesty in graduate business programs: Prevalence, causes, and proposed action. Academy of Management Learning \& Education, 5: 294-305

Nonis, S., \& Swift, C.O. 2001. An examination of the relationship between academic dishonesty and workplace dishonesty: A multicampus investigation. Journal of Education for Business, 76: 69-77.

Perez-Gonzalez, F. 2006. Inherited control and firm performance. American Economics Review, 96 (5): $1559-1588$

Philippon, T., \& Reshef, A. 2012. Wages and human capital in the US finance industry:1909 2006, The Quarterly Journal of Economics, 127(4): 1551-1609

Roberts, S., \& Rosenberg, I. 2006. Nutrition and aging: changes in the regulation of energy metabolism with aging. Physiological Reviews, 86: 651-667.

Rose, C. 2007. Does female board representation influence firm performance? The Danish evidence, Corporate Governance: An International Review, 15 (2): 403-413

Rosenstein, S., \& Wyatt, J.G. 1997. Inside directors, board effectiveness and shareholder wealth. Journal of Financial Economics, 44: 229-250.

Shivdasani, A., \& Yermack, D. 1999. CEO involvement in the selection of board members: An empirical analysis. Journal of Finance, 54(5): 1829-1853

Song, F., \& Thakor, A.V. 2006, Information control, career concerns, and corporate governance, Journal of Finance, 61(4): 1845-96

Singh, V., Vinnicombe, S., \& Johnson, P. 2001. Women directors on top UK boards, Corporate Governance: An International Review, 12 (4): 479-488 
Terjesen, S., Sealy, R., \& Singh, V. 2009. Women directors on corporate boards: A review and research agenda, Corporate Governance: An International Review, 17 (3): 320-337

Van Essen, M., Engelen, P.J. \& Carney, M. 2013. Does good corporate governance help in a crisis? The impact of country- and Firm-level governance mechanisms in the European Financial crisis. Corporate Governance: An International Review, 21(3): 201-224

Ward, A.J., Brown, J.A., \& Rodriguez, D. 2009. Governance bundles, firm performance, and the substitutability and complementarity of governance mechanisms. Corporate Governance: An International Review, 17(5): 646-660

Warner, J.B., Watts, R.L., \& Wruck, K.H. 1988. Stock prices and top management changes. Journal of Financial Economics, 20: 461-492

Worthy, D.A., Gorlick, M.A., Pacheco, J.L., Schnyer, D.M., \& Maddox, W.T., 2011. With age comes wisdom: Decision-making in older and younger adults. Psychology Science, 22(11): 1375-1380

Yim, S. 2013. The acquisitiveness of youth: CEO age and acquisition behaviours. Journal of Financial Economics, 108 (1): 461-492 


\section{TABLE 1}

\section{Sample distribution}

This table reports the composition of the sample of 658 announcements of executive appointments to 308 US banks between 01 January 1999 and 31 December 2011. Based on the information provided in the newspapers announcements, we classify the appointment announcements into three categories: (1) single and externally-hired appointment announcements, (2) single and internally-promoted appointment announcements, and (3) multiple executive appointment announcements. For clarity, we further classify 252 single and externally-hired appointment announcements into joining announcements and joining mixed with planned retirement announcements.

Number

\section{Single and externally-hired appointment announcements}

Joining announcements of the incoming executives

Joining mixed with planned retirement announcements

Single and internally-promoted appointment announcements

\section{Multiple appointment announcements}

All internal candidates

99

At least one external candidate

36 
TABLE 2

\section{Summary Statistics}

This table reports the descriptive statistics of the variables in our sample. The sample consists of 252 single externally-hired executive appointment announcements to 145 US banks between 01 January 1999 and 31 December 2011.

\begin{tabular}{|c|c|c|c|c|c|c|}
\hline Variable & Definition & $\mathbf{N}$ & Mean & SD & p1 & p99 \\
\hline \multicolumn{7}{|l|}{ Panel A: Executive characteristics } \\
\hline AGE & The age of the appointee & 252 & 49.47 & 6.54 & 35.00 & 66.00 \\
\hline FEMALE & $\begin{array}{l}\text { Dummy that equals to } 1 \text { if the appointee is a } \\
\text { female and } 0 \text { otherwise. }\end{array}$ & 252 & 0.06 & 0.24 & 0.00 & 1.00 \\
\hline \#EXECUTIVE DIRECTORSHIPS & $\begin{array}{l}\text { Number of executive directorships at listed firms } \\
\text { that the appointee holds prior to joining the bank }\end{array}$ & 252 & 0.69 & 0.86 & 0.00 & 4.00 \\
\hline BUSYNESS & $\begin{array}{l}\text { Number of non-executive directorships the } \\
\text { appointee holds at the time of the appointment. }\end{array}$ & 252 & 0.06 & 0.32 & 0.00 & 2.00 \\
\hline \#NON-BANKING INDUSTRIES & $\begin{array}{l}\text { Number of non-banking industries the appointee } \\
\text { has worked in prior to joining the bank. }\end{array}$ & 252 & 0.25 & 0.80 & 0.00 & 5.00 \\
\hline IVY LEAGUE & $\begin{array}{l}\text { Dummy that equals to } 1 \text { if the appointee obtains at } \\
\text { least one degree from Ivy League institutions and } 0 \\
\text { otherwise }\end{array}$ & 252 & 0.15 & 0.35 & 0.00 & 1.00 \\
\hline MBA & $\begin{array}{l}\text { Dummy that equals to } 1 \text { if the appointee possesses } \\
\text { an MBA degree and } 0 \text { otherwise }\end{array}$ & 252 & 0.46 & 0.50 & 0.00 & 1.00 \\
\hline \multicolumn{7}{|l|}{ Panel B: Bank characteristics } \\
\hline ROA & $\begin{array}{l}\text { Earnings before interests and taxes (EBIT) divided } \\
\text { by book value of total assets. }\end{array}$ & 252 & 1.26 & 1.27 & -2.63 & 5.63 \\
\hline BANKSIZE & Natural logarithm of total assets & 252 & 22.84 & 2.06 & 19.49 & 28.41 \\
\hline PORTFOLIO RISK & $\begin{array}{l}\text { Risk-weighted assets divided by book value of } \\
\text { total assets }\end{array}$ & 252 & 0.76 & 0.28 & 0.03 & 0.93 \\
\hline CHARTER VALUE & $\begin{array}{l}\text { Market value of equity divided by book value of } \\
\text { equity }\end{array}$ & 252 & 1.67 & 1.06 & 0.13 & 4.60 \\
\hline LEVERAGE & $\begin{array}{l}\text { Book value of liabilities divided the book value of } \\
\text { equity }\end{array}$ & 252 & 9.95 & 3.50 & 1.52 & 19.68 \\
\hline BOARDSIZE & $\begin{array}{l}\text { Number of executive and non-executive directors } \\
\text { on the board. }\end{array}$ & 252 & 12.10 & 3.58 & 6.00 & 21.00 \\
\hline BOARDIND & $\begin{array}{l}\text { The proportion of non-executive directors on the } \\
\text { board. }\end{array}$ & 252 & 0.76 & 0.14 & 0.25 & 0.93 \\
\hline DUALITY & $\begin{array}{l}\text { Dummy that equals to } 1 \text { if the CEO is also a } \\
\text { Chairman and } 0 \text { otherwise }\end{array}$ & 252 & 0.52 & 0.50 & 0.00 & 1.00 \\
\hline CEOINNOM & $\begin{array}{l}\text { Dummy that equals to } 1 \text { if the CEO sits in the } \\
\text { nominating committee and } 0 \text { otherwise }\end{array}$ & 252 & 0.10 & 0.30 & 0.00 & 1.00 \\
\hline CEOPOST & $\begin{array}{l}\text { CEOPOST equals to } 1 \text { if the appointee is } \\
\text { appointed to a CEO position and } 0 \text { otherwise. }\end{array}$ & 252 & 0.27 & 0.43 & 0.00 & 1.00 \\
\hline DISTANCE_AIRPORT & $\begin{array}{l}\text { The distance from the bank's headquarter to the } \\
\text { nearest international airport (miles) }\end{array}$ & 252 & 18.23 & 19.50 & 0.7 & 104 \\
\hline
\end{tabular}


TABLE 3

Correlation matrix

This table presents the pairwise correlation coefficients between the variables used in the regression analysis. All other variables are defined in Table 2 . Bold coefficients denote statistical significance at $5 \%$ level.

\begin{tabular}{|c|c|c|c|c|c|c|c|c|c|c|c|c|c|c|c|c|c|c|c|}
\hline & (1) & (2) & (3) & (4) & (5) & (6) & (7) & (8) & (9) & (10) & (11) & (12) & (13) & (14) & (15) & (16) & (17) & (18) & (19) \\
\hline (1) 5-day CAR (\%) & 1.00 & & & & & & & & & & & & & & & & & & \\
\hline (2) AGE & 0.08 & 1.00 & & & & & & & & & & & & & & & & & \\
\hline (3) FEMALE & 0.00 & -0.06 & 1.00 & & & & & & & & & & & & & & & & \\
\hline (4) \#EXEC DIRECTORSHIPS & 0.08 & 0.22 & -0.06 & 1.00 & & & & & & & & & & & & & & & \\
\hline (5) BUSYNESS & -0.10 & 0.18 & 0.05 & 0.12 & 1.0 & & & & & & & & & & & & & & \\
\hline (6) \#NON-BANK INDUSTRIES & -0.06 & 0.17 & -0.02 & 0.22 & 0.60 & 1.00 & & & & & & & & & & & & & \\
\hline (7) IVY LEAGUE & 0.10 & 0.11 & -0.06 & 0.03 & 0.09 & 0.05 & 1.00 & & & & & & & & & & & & \\
\hline (8) MBA & 0.01 & 0.05 & 0.12 & 0.09 & 0.02 & 0.11 & 0.09 & 1.00 & & & & & & & & & & & \\
\hline (9) $\mathrm{ROA}$ & -0.07 & -0.27 & -0.01 & -0.12 & -0.05 & -0.07 & 0.03 & -0.03 & 1.00 & & & & & & & & & & \\
\hline (10) BANKSIZE & 0.04 & 0.09 & 0.10 & 0.18 & 0.26 & 0.30 & 0.22 & 0.00 & 0.05 & 1.00 & & & & & & & & & \\
\hline (11) PORTFOLIO RISK & -0.01 & 0.02 & 0.09 & 0.04 & 0.04 & -0.04 & -0.02 & -0.03 & 0.01 & 0.00 & 1.00 & & & & & & & & \\
\hline (12) CHARTERVALUE & -0.16 & -0.11 & -0.02 & -0.04 & -0.05 & -0.03 & 0.07 & -0.02 & 0.65 & 0.02 & 0.04 & 1.00 & & & & & & & \\
\hline (13) LEVERAGE & 0.01 & 0.00 & -0.09 & 0.07 & 0.00 & 0.07 & 0.10 & 0.03 & -0.19 & 0.18 & 0.01 & 0.00 & 1.00 & & & & & & \\
\hline (14) BOARDSIZE & 0.03 & 0.02 & 0.00 & -0.01 & 0.15 & 0.11 & 0.06 & 0.05 & 0.01 & 0.33 & 0.14 & 0.12 & 0.03 & 1.00 & & & & & \\
\hline (15) BOARDIND & 0.08 & -0.04 & 0.06 & 0.13 & 0.08 & 0.08 & 0.04 & 0.03 & -0.26 & 0.19 & 0.06 & -0.26 & 0.02 & 0.05 & 1.00 & & & & \\
\hline (16) DUALITY & 0.03 & -0.09 & 0.15 & -0.02 & -0.03 & -0.08 & 0.09 & 0.04 & 0.09 & 0.22 & 0.04 & 0.07 & 0.08 & 0.09 & -0.05 & 1.00 & & & \\
\hline (17) CEOINNOM & 0.04 & -0.06 & -0.09 & -0.09 & -0.03 & -0.06 & -0.07 & 0.03 & 0.07 & -0.16 & 0.01 & 0.08 & -0.01 & -0.01 & -0.26 & -0.04 & 1.00 & & \\
\hline (18) CEOPOST & -0.07 & 0.17 & -0.12 & 0.08 & -0.06 & -0.07 & 0.08 & 0.06 & -0.09 & -0.23 & 0.07 & 0.01 & 0.03 & -0.15 & -0.09 & -0.22 & 0.02 & 1.00 & \\
\hline (19) DISTANCE_AIRPORT & -0.10 & 0.01 & -0.04 & -0.06 & -0.07 & -0.13 & -0.06 & -0.02 & -0.03 & -0.26 & 0.11 & -0.05 & 0.06 & -0.01 & -0.08 & -0.05 & 0.09 & 0.24 & 1.00 \\
\hline
\end{tabular}


TABLE 4

Probit estimates of probability of single and externally-hired appointments

This table estimates the likelihood that the bank is going to make single and externally-hired appointments. This analysis is estimated over the full sample of 658 executive appointment announcements, including single and externally-hired appointment announcements (our sample of interest), single and internally-promoted appointment announcements, and multiple executive appointment announcements. The dependent variable is a dummy that equals to 1 if the bank makes a single and externally-hired appointment. Year fixed-effects are included. All other variables are defined in Table 2. t-statistics are reported in brackets. The symbols $* * *, * *, *, \dagger$ denote significance at the $0.1 \%, 1 \%, 5 \%$ and $10 \%$ level, respectively.

\begin{tabular}{|c|c|c|c|}
\hline & (1) & (2) & (3) \\
\hline \multicolumn{4}{|l|}{ Appointee-level characteristics } \\
\hline \multirow[t]{2}{*}{ AGE } & $-0.01 \dagger$ & -0.01 & -0.01 \\
\hline & $(-1.69)$ & $(-1.47)$ & $(-1.49)$ \\
\hline \multirow[t]{2}{*}{ FEMALE } & -0.36 & -0.37 & -0.33 \\
\hline & $(-1.55)$ & $(-1.58)$ & $(-1.39)$ \\
\hline \multirow[t]{2}{*}{ \#EXECUTIVE DIRECTORSHIPS } & $-0.38 * * *$ & $-0.39 * * *$ & $-0.39 * * *$ \\
\hline & $(-4.04)$ & $(-4.15)$ & $(-4.19)$ \\
\hline \multirow[t]{2}{*}{ BUSYNESS } & -0.27 & -0.26 & -0.27 \\
\hline & $(-1.34)$ & $(-1.29)$ & $(-1.31)$ \\
\hline \multirow[t]{2}{*}{ \#NON-BANKING INDUSTRIES } & $0.17 \dagger$ & $0.17 \dagger$ & 0.15 \\
\hline & $(1.84)$ & $(1.79)$ & $(1.61)$ \\
\hline \multirow[t]{2}{*}{ IVY LEAGUE } & $0.30 \dagger$ & 0.28 & 0.26 \\
\hline & $(1.75)$ & $(1.61)$ & $(1.44)$ \\
\hline \multirow[t]{2}{*}{ MBA } & $0.50 * * *$ & $0.51 * * *$ & $0.53 * * *$ \\
\hline & $(4.40)$ & $(4.48)$ & $(4.57)$ \\
\hline \multicolumn{4}{|l|}{ Bank-level characteristics } \\
\hline \multirow[t]{2}{*}{ ROA } & 0.08 & 0.09 & 0.09 \\
\hline & $(1.35)$ & $(1.41)$ & $(1.44)$ \\
\hline \multirow[t]{2}{*}{ BANKSIZE } & -0.02 & -0.01 & -0.04 \\
\hline & $(-0.59)$ & $(-0.44)$ & $(-1.20)$ \\
\hline \multirow[t]{2}{*}{ PORTFOLIO RISK } & 0.17 & 0.16 & 0.14 \\
\hline & $(1.24)$ & $(1.17)$ & $(0.97)$ \\
\hline \multirow[t]{2}{*}{ CHARTERVALUE } & $-0.18 * *$ & $-0.18^{*}$ & $-0.18^{*}$ \\
\hline & $(-2.59)$ & $(-2.39)$ & $(-2.39)$ \\
\hline \multirow[t]{2}{*}{ LEVERAGE } & -0.01 & -0.01 & -0.01 \\
\hline & $(-0.83)$ & $(-0.81)$ & $(-0.81)$ \\
\hline \multirow[t]{2}{*}{ BOARDSIZE } & -0.02 & -0.02 & -0.02 \\
\hline & $(-1.35)$ & $(-1.27)$ & $(-1.04)$ \\
\hline \multirow[t]{2}{*}{ BOARDIND } & 0.61 & 0.39 & 0.38 \\
\hline & $(1.42)$ & $(0.82)$ & $(0.79)$ \\
\hline \multirow[t]{2}{*}{ DUALITY } & -0.14 & -0.16 & -0.14 \\
\hline & $(-1.28)$ & $(-1.45)$ & $(-1.28)$ \\
\hline \multirow[t]{2}{*}{ CEOINNOM } & $0.33 \dagger$ & $0.42 *$ & $0.46^{*}$ \\
\hline & $(1.82)$ & $(2.05)$ & $(2.21)$ \\
\hline \multirow[t]{2}{*}{ CEOPOST } & $-0.56 * * *$ & $-0.57 * * *$ & $-0.52 * * *$ \\
\hline & $(-4.02)$ & $(-4.01)$ & $(-3.66)$ \\
\hline \multirow[t]{2}{*}{ POST_CRISIS } & 0.06 & -0.14 & -0.15 \\
\hline & $(0.41)$ & $(-0.28)$ & $(-0.30)$ \\
\hline \multirow[t]{2}{*}{ DISTANCE_AIRPORT } & & & $-0.22 * * *$ \\
\hline & & & $(-3.96)$ \\
\hline Year fixed-effects & No & Yes & Yes \\
\hline Pseudo R-squared & $11.73 \%$ & $12.58 \%$ & $14.19 \%$ \\
\hline Observations & 658 & 658 & 658 \\
\hline
\end{tabular}


TABLE 5

The stock market reaction to announcements of single and externally-hired appointments

This table shows the stock price reactions to 252 single and externally-hired executive appointment announcements to 145 US banks between 01 January 1999 and 31 December 2011. We report abnormal returns for different event windows surrounding executive appointment announcements. In addition to the mean and the median abnormal return, we also report the Patell-Z test, the Wilcoxon sign-raked test and the percentage of positive abnormal returns. The symbols $* * *, * *, *, \dagger$ denote significance at the $0.1 \%, 1 \%, 5 \%$ and $10 \%$ level, respectively.

\begin{tabular}{lcccccc}
\hline Event window & N & Average CAR $(\%)$ & Patell-Z & Median CARs & Sign-ranked & \% Positive CARs \\
\hline-1 to 0 day & 252 & 0.71 & 1.14 & 0.18 & 0.99 & 52.8 \\
0 to + 2 day & 252 & 0.31 & 0.55 & -0.16 & 0.07 & 48.0 \\
0 to + 3 day & 252 & 0.47 & 0.74 & 0.14 & 0.49 & 52.0 \\
0 to + 4 day & 252 & 0.99 & $1.96^{*}$ & 0.24 & $1.65^{*}$ & 53.2 \\
\hline
\end{tabular}


TABLE 6

Appointee characteristics and stock market reactions to executive appointments

This table reports the results of multivariate Heckman (1979) regression analyses of stock market reactions to the announcements of single and externally-hired executive appointments. The dependent variables of all models are 5day CAR (\%). POST_CRISIS equals to 1 if year is 2008-2011 and 0 otherwise. LAMBDA represents the inverse Mill's ratio of the first stage probit regression that estimates the likelihood of the bank making a single externallyhired executive appointment announcement. Standard errors are clustered at bank-level. All other variables are defined in Table 2. t-statistics are reported in brackets. The symbols $* * *, * *, *, \dagger$ denote significance at the $0.1 \%$, $1 \%, 5 \%$ and $10 \%$ level, respectively

\begin{tabular}{|c|c|c|c|c|c|c|c|c|}
\hline & (1) & (2) & (3) & $(4)$ & $(5)$ & (6) & (7) & (8) \\
\hline AGE & $\begin{array}{l}0.12 \dagger \\
(1.77)\end{array}$ & & & & & & & $\begin{array}{l}0.13^{*} \\
(1.99)\end{array}$ \\
\hline FEMALE & & $\begin{array}{c}-0.76 \\
(-0.44)\end{array}$ & & & & & & $\begin{array}{c}1.21 \\
(0.79)\end{array}$ \\
\hline \#EXEC DIRECTORSHIPS & & & $\begin{array}{l}1.36^{*} \\
(2.43)\end{array}$ & & & & & $\begin{array}{l}1.53^{* * *} \\
(2.89)\end{array}$ \\
\hline BUSYNESS & & & & $\begin{array}{c}-3.27 * * \\
(-2.60)\end{array}$ & & & & $\begin{array}{c}-3.91 * * * \\
(-3.46)\end{array}$ \\
\hline \#NON-BANK INDUSTRIES & & & & & $\begin{array}{c}-0.34 \\
(-0.80)\end{array}$ & & & - \\
\hline IVY LEAGUE & & & & & & $\begin{array}{l}3.52 * \\
(2.12)\end{array}$ & & $\begin{array}{l}2.15 \dagger \\
(1.65)\end{array}$ \\
\hline MBA & & & & & & & $\begin{array}{c}1.83 \\
(1.56)\end{array}$ & $\begin{array}{l}-1.42 \\
(-1.62)\end{array}$ \\
\hline ROA & $\begin{array}{c}0.60 \\
(0.93)\end{array}$ & $\begin{array}{c}1.27 \dagger \\
(1.85)\end{array}$ & $\begin{array}{c}0.43 \\
(0.67)\end{array}$ & $\begin{array}{l}1.22 \dagger \\
(1.78)\end{array}$ & $\begin{array}{l}1.24 \dagger \\
(1.81)\end{array}$ & $\begin{array}{l}1.20 \dagger \\
(1.72)\end{array}$ & $\begin{array}{l}1.34 \dagger \\
(1.92)\end{array}$ & $\begin{array}{c}0.58 \\
(0.86)\end{array}$ \\
\hline BANKSIZE & $\begin{array}{c}-0.18 \\
(-0.82)\end{array}$ & $\begin{array}{c}-0.41 \\
(-1.60)\end{array}$ & $\begin{array}{c}-0.17 \\
(-0.88)\end{array}$ & $\begin{array}{c}-0.27 \\
(-1.07)\end{array}$ & $\begin{array}{c}-0.37 \\
(-1.43)\end{array}$ & $\begin{array}{l}-0.54^{*} \\
(-2.01)\end{array}$ & $\begin{array}{l}-0.43 \dagger \\
(-1.66)\end{array}$ & $\begin{array}{c}-0.20 \\
(-0.91)\end{array}$ \\
\hline PORTFOLIO RISK & $\begin{array}{c}-0.45 \\
(-0.45)\end{array}$ & $\begin{array}{c}0.01 \\
(0.01)\end{array}$ & $\begin{array}{c}-0.58 \\
(-0.56)\end{array}$ & $\begin{array}{l}-0.04 \\
(-0.03)\end{array}$ & $\begin{array}{l}-0.10 \\
(-0.07)\end{array}$ & $\begin{array}{l}-0.05 \\
(-0.04)\end{array}$ & $\begin{array}{c}0.08 \\
(0.06)\end{array}$ & $\begin{array}{c}-0.78 \\
(-0.68)\end{array}$ \\
\hline CHARTERVALUE & $\begin{array}{l}-1.11 \dagger \\
(-1.66)\end{array}$ & $\begin{array}{c}-2.07 * * \\
(-3.01)\end{array}$ & $\begin{array}{l}-0.86 \\
(-1.39)\end{array}$ & $\begin{array}{l}-2.02 * * \\
(-2.90)\end{array}$ & $\begin{array}{l}-2.04 * * \\
(-2.97)\end{array}$ & $\begin{array}{c}-2.09 * * \\
(-3.07)\end{array}$ & $\begin{array}{c}-2.11 * * \\
(-3.03)\end{array}$ & $\begin{array}{l}-0.98 \\
(-1.64)\end{array}$ \\
\hline LEVERAGE & $\begin{array}{c}0.07 \\
(0.63)\end{array}$ & $\begin{array}{c}0.02 \\
(0.10)\end{array}$ & $\begin{array}{c}0.08 \\
(0.74)\end{array}$ & $\begin{array}{c}0.00 \\
(0.03)\end{array}$ & $\begin{array}{c}0.02 \\
(0.13)\end{array}$ & $\begin{array}{l}-0.00 \\
(-0.03)\end{array}$ & $\begin{array}{c}0.02 \\
(0.12)\end{array}$ & $\begin{array}{c}0.08 \\
(0.74)\end{array}$ \\
\hline BOARDSIZE & $\begin{array}{c}0.09 \\
(0.89)\end{array}$ & $\begin{array}{c}-0.01 \\
(-0.06)\end{array}$ & $\begin{array}{c}0.13 \\
(1.18)\end{array}$ & $\begin{array}{c}0.03 \\
(0.19)\end{array}$ & $\begin{array}{l}-0.00 \\
(-0.03)\end{array}$ & $\begin{array}{c}-0.01 \\
(-0.05)\end{array}$ & $\begin{array}{c}-0.03 \\
(-0.21)\end{array}$ & $\begin{array}{c}0.19^{\dagger} \\
(1.70)\end{array}$ \\
\hline BOARDIND & $\begin{array}{c}5.79 \\
(1.42)\end{array}$ & $\begin{array}{l}10.60 * \\
(2.49)\end{array}$ & $\begin{array}{c}3.75 \\
(0.97)\end{array}$ & $\begin{array}{l}9.95^{*} \\
(2.34)\end{array}$ & $\begin{array}{l}10.48^{*} \\
(2.46)\end{array}$ & $\begin{array}{l}10.34 * \\
(2.45)\end{array}$ & $\begin{array}{l}10.35^{*} \\
(2.42)\end{array}$ & $\begin{array}{c}4.49 \\
(1.16)\end{array}$ \\
\hline CEOINNOM & $\begin{array}{c}0.36 \\
(0.43)\end{array}$ & $\begin{array}{c}-0.61 \\
(-0.59)\end{array}$ & $\begin{array}{c}0.43 \\
(0.51)\end{array}$ & $\begin{array}{c}-0.73 \\
(-0.70)\end{array}$ & $\begin{array}{c}-0.71 \\
(-0.67)\end{array}$ & $\begin{array}{c}-0.80 \\
(-0.79)\end{array}$ & $\begin{array}{c}-0.81 \\
(-0.77)\end{array}$ & $\begin{array}{c}0.33 \\
(0.36)\end{array}$ \\
\hline DUALITY & $\begin{array}{c}0.60 \\
(0.29)\end{array}$ & $\begin{array}{c}1.54 \\
(0.66)\end{array}$ & $\begin{array}{c}0.25 \\
(0.13)\end{array}$ & $\begin{array}{c}1.79 \\
(0.78)\end{array}$ & $\begin{array}{c}1.58 \\
(0.68)\end{array}$ & $\begin{array}{c}1.67 \\
(0.76)\end{array}$ & $\begin{array}{c}1.65 \\
(0.71)\end{array}$ & $\begin{array}{c}0.66 \\
(0.34)\end{array}$ \\
\hline CEOPOST & $\begin{array}{c}-0.68 \\
(-0.41)\end{array}$ & $\begin{array}{l}-4.09^{*} \\
(-2.07)\end{array}$ & $\begin{array}{c}0.03 \\
(0.02)\end{array}$ & $\begin{array}{l}-3.81^{*} \\
(-1.97)\end{array}$ & $\begin{array}{l}-4.03^{*} \\
(-2.06)\end{array}$ & $\begin{array}{l}-4.42^{*} \\
(-2.31)\end{array}$ & $\begin{array}{l}-4.48^{*} \\
(-2.21)\end{array}$ & $\begin{array}{c}-0.12 \\
(-0.09)\end{array}$ \\
\hline POST_CRISIS & $\begin{array}{c}-4.41 \\
(-1.21)\end{array}$ & $\begin{array}{l}-7.74 \dagger \\
(-1.82)\end{array}$ & $\begin{array}{c}-4.69 \\
(-1.33)\end{array}$ & $\begin{array}{l}-7.04 \dagger \\
(-1.67)\end{array}$ & $\begin{array}{l}-7.73 \dagger \\
(-1.83)\end{array}$ & $\begin{array}{l}-7.72 \dagger \\
(-1.83)\end{array}$ & $\begin{array}{l}-7.70 \dagger \\
(-1.81)\end{array}$ & $\begin{array}{c}-4.76 \\
(-1.33)\end{array}$ \\
\hline LAMBDA & $\begin{array}{c}0.08 \\
(0.03)\end{array}$ & $\begin{array}{c}7.51 * * * \\
(4.40)\end{array}$ & $\begin{array}{l}-1.77 \\
(-1.21)\end{array}$ & $\begin{array}{c}7.21 * * * \\
(4.12)\end{array}$ & $\begin{array}{c}7.46 \text { *** } \\
(4.70)\end{array}$ & $\begin{array}{c}7.45^{* * * *} \\
(4.39)\end{array}$ & $\begin{array}{c}7.77 * * * \\
(4.68)\end{array}$ & $\begin{array}{l}-1.90 * \\
(2.34)\end{array}$ \\
\hline Time fixed-effects & Yes & Yes & Yes & Yes & Yes & Yes & Yes & Yes \\
\hline Single external appointments & 252 & 252 & 252 & 252 & 252 & 252 & 252 & 252 \\
\hline R-Squared & $9.56 \%$ & $8.60 \%$ & $9.87 \%$ & $10.93 \%$ & $9.11 \%$ & $9.66 \%$ & $8.58 \%$ & $16.36 \%$ \\
\hline
\end{tabular}


TABLE 7

\section{Additional evidence on the value of appointee characteristics}

This table reports the results of multivariate Heckman (1979) regression analyses of stock market reactions to the announcements of single and externally-hired appointments for different specifications. Column 1 reports the coefficient estimates for an alternative event window of $(0,+3)$. Column 2 reports the coefficient estimates for an alternative estimation period of $(-146,-46)$. Column 3 reports the coefficient estimates using an alternative benchmark of Datastream US banks Index (BANKSUS). Column 4 excludes announcements that contain sentiments. Column 5 adds bank fixed-effects into our model. Column 6 performs a placebo regression on event window $(-15,-13)$. Standard errors are clustered at bank-level. t-statistics are reported in brackets. For brevity, we do not show the control variables. The symbols $* * *, * *, *, \dagger$ denote significance at the $0.1 \%, 1 \%, 5 \%$ and $10 \%$ level, respectively

\begin{tabular}{|c|c|c|c|c|c|c|}
\hline & (1) & (2) & (3) & (4) & $(5)$ & (6) \\
\hline & $\begin{array}{l}\text { CAR } \\
(0,+3)\end{array}$ & $\begin{array}{c}\text { Estimation } \\
\text { period } \\
(-146,-46)\end{array}$ & $\begin{array}{c}\text { Datastream } \\
\text { US banks } \\
\text { index }\end{array}$ & $\begin{array}{c}\text { Non- } \\
\text { sentimental }\end{array}$ & $\begin{array}{c}\text { Bank } \\
\text { Fixed-effects }\end{array}$ & $\begin{array}{c}\text { Placebo } \\
\text { CARs } \\
(-15,-13) \\
\end{array}$ \\
\hline \multirow[t]{2}{*}{ AGE } & $0.13 *$ & $0.17 *$ & $0.08 \dagger$ & $0.13 \dagger$ & $0.23 * *$ & 0.02 \\
\hline & $(2.49)$ & $(2.09)$ & $(1.84)$ & $(1.98)$ & $(2.84)$ & $(0.20)$ \\
\hline \multirow[t]{2}{*}{ GENDER } & 1.13 & -0.08 & 0.99 & 1.25 & 3.13 & 1.47 \\
\hline & $(0.86)$ & $(-0.05)$ & $(0.73)$ & $(0.80)$ & $(1.56)$ & $(0.45)$ \\
\hline \multirow[t]{2}{*}{ \#EXECUTIVE DIRECTORSHIPS } & $1.34 * *$ & $1.85^{* *}$ & 0.47 & $1.49 * *$ & 1.13 & 0.45 \\
\hline & $(2.96)$ & $(2.73)$ & $(1.42)$ & $(2.79)$ & $(0.77)$ & $(0.13)$ \\
\hline \multirow[t]{2}{*}{ BUSYNESS } & $-3.84 * * *$ & $-3.72 *$ & $-1.77 * *$ & $-3.97 * * *$ & $-6.10 * * *$ & -0.25 \\
\hline & $(-3.22)$ & $(-2.53)$ & $(-2.82)$ & $(-3.51)$ & $(-5.12)$ & $(-0.25)$ \\
\hline \multirow[t]{2}{*}{ IVY LEAGUE } & $2.01 \dagger$ & 2.17 & $1.80^{*}$ & 1.81 & 0.86 & 0.34 \\
\hline & $(1.69)$ & $(1.59)$ & $(1.97)$ & $(1.36)$ & $(0.71)$ & $(0.39)$ \\
\hline \multirow[t]{2}{*}{ MBA } & -0.93 & -1.73 & -0.57 & $-1.48 \dagger$ & -2.53 & -0.86 \\
\hline & $(-1.23)$ & $(-1.49)$ & $(-0.84)$ & $(-1.66)$ & $(-1.17)$ & $(-0.18)$ \\
\hline Other control variables & Yes & Yes & Yes & Yes & Yes & Yes \\
\hline Time-fixed effects & Yes & Yes & Yes & Yes & Yes & Yes \\
\hline Single external appointments & 252 & 252 & 252 & 242 & 252 & 252 \\
\hline R-Squared & $21.23 \%$ & $15.06 \%$ & $14.58 \%$ & $13.30 \%$ & $69.43 \%$ & $7.12 \%$ \\
\hline
\end{tabular}




\section{TABLE 8}

Appointee characteristics, board independence and stock market reactions to executive appointments

This table reports the results of multivariate Heckman (1979) regression analyses of stock market reactions to announcements of single and externally-hired appointments. The dependent variables of all models are 5-day CAR (\%). CHARACTERISTIC refers to the appointee characteristic shown in the column specification. BOARDIND is the proportion of non-executive directors on a board. LAMBDA represents the inverse Mill's ratio of the first stage probit regression that estimates the likelihood of the bank making a single externally-hired executive appointment announcement. Standard errors are clustered at bank-level. t-statistics are reported in brackets. For brevity, we do not show the control variables. The symbols $* * *, * *, *, \dagger$ denote significance at the $0.1 \%, 1 \%, 5 \%$ and $10 \%$ level, respectively.

\begin{tabular}{|c|c|c|c|c|c|c|c|}
\hline & AGE & FEMALE & $\begin{array}{c}\text { \# EXEC } \\
\text { DIRECTORSHIPS }\end{array}$ & BUSYNESS & $\begin{array}{c}\text { \# NON } \\
\text { BANKING }\end{array}$ & $\begin{array}{c}\text { IVY } \\
\text { LEAGUE }\end{array}$ & MBA \\
\hline \multicolumn{8}{|c|}{ Panel A: Regression results } \\
\hline \multirow[t]{2}{*}{ BOARDIND*CHARACTERISTIC } & -0.11 & 17.00 & $-7.12 *$ & 4.95 & $-6.54 *$ & $-10.48 \dagger$ & 3.89 \\
\hline & $(-0.21)$ & $(1.42)$ & $(-2.09)$ & $(0.29)$ & $(-2.26)$ & $(-1.82)$ & $(0.70)$ \\
\hline \multirow[t]{2}{*}{ CHARACTERISTIC } & 0.20 & -14.12 & 6.87 & -7.26 & $4.91 *$ & $10.14 *$ & -1.15 \\
\hline & $(0.48)$ & $(-1.43)$ & $(0.82)$ & $(-0.56)$ & $(2.22)$ & $(2.26)$ & $(-0.25)$ \\
\hline \multirow[t]{2}{*}{ BOARDIND } & 11.12 & $10.06^{* *}$ & 8.51 & $9.81 * *$ & $7.06^{*}$ & $7.38^{* *}$ & 8.54 \\
\hline & $(0.44)$ & $(2.39)$ & $(0.52)$ & $(2.32)$ & $(2.32)$ & $(2.67)$ & $(1.62)$ \\
\hline \multirow[t]{2}{*}{ LAMBDA } & 0.09 & $7.51^{* * *}$ & -1.97 & $7.20 * * *$ & $7.52 * * *$ & $7.31 * * *$ & $7.78 * * *$ \\
\hline & $(0.04)$ & $(4.51)$ & $(-0.07)$ & $(4.07)$ & $(4.61)$ & $(4.62)$ & $(4.72)$ \\
\hline Other control variables & Yes & Yes & Yes & Yes & Yes & Yes & Yes \\
\hline Time fixed-effects & Yes & Yes & Yes & Yes & Yes & Yes & Yes \\
\hline Single external appointments & 252 & 252 & 252 & 252 & 252 & 252 & 252 \\
\hline R-Squared & $9.58 \%$ & $8.68 \%$ & $10.23 \%$ & $11.09 \%$ & $9.11 \%$ & $11.45 \%$ & $8.65 \%$ \\
\hline \multicolumn{8}{|c|}{ Panel B: H0 = BOARDIND*CHARACTERISTIC + CHARACTERISTIC = 0} \\
\hline F-test & 0.52 & 1.07 & 0.13 & 0.33 & 1.33 & 0.01 & $2.92 \dagger$ \\
\hline Prob $>\mathrm{Chi}^{2}$ & $(0.47)$ & $(0.30)$ & $(0.72)$ & $(0.57)$ & $(0.25)$ & $(0.94)$ & $(0.09)$ \\
\hline
\end{tabular}




\section{TABLE 9}

\section{Appointee characteristics, CEO dummy and stock market reactions to executive appointments}

This table reports the results of multivariate Heckman (1979) regression analyses of stock market reactions to announcements of single and externally-hired appointments. The dependent variables of all models are 5-day CAR (\%). CHARACTERISTIC refers to the appointee characteristic shown in the column specification. CEOPOST equals to 1 if the appointee is appointed to a CEO position and 0 otherwise. LAMBDA represents the inverse Mill's ratio of the first stage probit regression that estimates the likelihood of the bank making a single externally-hired executive appointment announcement. Standard errors are clustered at bank-level. t-statistics are reported in brackets. For brevity, we do not show the control variables. The symbols $* * *, * *, *, \dagger$ denote significance at the $0.1 \%, 1 \%, 5 \%$ and $10 \%$ level, respectively.

\begin{tabular}{|c|c|c|c|c|c|c|}
\hline & AGE & $\begin{array}{c}\text { \# EXEC } \\
\text { DIRECTORSHIPS }\end{array}$ & BUSYNESS & $\begin{array}{c}\text { \# NON- } \\
\text { BANKING }\end{array}$ & $\begin{array}{c}\text { IVY } \\
\text { LEAGUE }\end{array}$ & MBA \\
\hline \multicolumn{7}{|c|}{ Panel A: Regression results } \\
\hline CEOPOST*CHARACTERISTIC & $\begin{array}{l}-0.04 \\
(-0.24)\end{array}$ & $\begin{array}{l}1.59 * \\
(2.03)\end{array}$ & $\begin{array}{c}-10.45^{* * *} \\
(-4.13)\end{array}$ & $\begin{array}{l}-0.81 \\
(-0.33)\end{array}$ & $\begin{array}{l}3.77 * \\
(2.10)\end{array}$ & $\begin{array}{c}1.79 \\
(0.81)\end{array}$ \\
\hline CHARACTERISTIC & $\begin{array}{l}0.12 \dagger \\
(1.75)\end{array}$ & $\begin{array}{l}0.74 \dagger \\
(1.68)\end{array}$ & $\begin{array}{l}-2.77 * \\
(-2.43)\end{array}$ & $\begin{array}{l}-0.52 \\
(-0.95)\end{array}$ & $\begin{array}{c}1.19 \\
(1.33)\end{array}$ & $\begin{array}{c}1.51 \\
(1.29)\end{array}$ \\
\hline CEOPOST & $\begin{array}{c}1.46 \\
(0.17)\end{array}$ & $\begin{array}{l}-1.47 \\
(-1.40)\end{array}$ & $\begin{array}{l}-3.47 * \\
(-1.96)\end{array}$ & $\begin{array}{c}-0.47 \\
(-0.37)\end{array}$ & $\begin{array}{l}-2.05^{*} \\
(-2.19)\end{array}$ & $\begin{array}{l}-5.40 * \\
(-2.07)\end{array}$ \\
\hline LAMBDA & $\begin{array}{c}0.08 \\
(0.03)\end{array}$ & $\begin{array}{l}-1.77 \\
(-1.21)\end{array}$ & $\begin{array}{c}7.22 * * * \\
(4.36)\end{array}$ & $\begin{array}{c}7.42^{* * *} \\
(4.04)\end{array}$ & $\begin{array}{c}7.42 * * * \\
(4.61)\end{array}$ & $\begin{array}{c}7.77 * * * \\
(4.71)\end{array}$ \\
\hline Other control variables & Yes & Yes & Yes & Yes & Yes & Yes \\
\hline Time fixed-effects & Yes & Yes & Yes & Yes & Yes & Yes \\
\hline Single external appointments & 252 & 252 & 252 & 252 & 252 & 252 \\
\hline R-Squared & $9.58 \%$ & $9.88 \%$ & $12.44 \%$ & $9.13 \%$ & $10.17 \%$ & $8.96 \%$ \\
\hline \multicolumn{7}{|c|}{ Panel B: H0 = CEOPOST $*$ CHARACTERISTIC + CHARACTERISTIC $=0$} \\
\hline $\begin{array}{l}\text { F-test } \\
\text { Prob> } \mathrm{Chi}^{2}\end{array}$ & $\begin{array}{c}0.24 \\
(0.62) \\
\end{array}$ & $\begin{array}{r}9.21^{* *} \\
(0.00) \\
\end{array}$ & $\begin{array}{c}27.61 * * * \\
(0.00) \\
\end{array}$ & $\begin{array}{r}0.30 \\
(0.59) \\
\end{array}$ & $\begin{array}{c}9.27 * * \\
(0.00) \\
\end{array}$ & $\begin{array}{r}1.90 \\
(0.17) \\
\end{array}$ \\
\hline
\end{tabular}

